\title{
ПОКАЗАТЕЛИ КАЧЕСТВА МЯСА ЦЫПЛЯТ-БРОЙЛЕРОВ (Gallus gallus L.) ПРИ ИСПОЛЬЗОВАНИИ В РАЦИОНАХ ФЕРМЕНТАТИВНЫХ ГИДРОЛИЗАТОВ ПЕРА И КОЛЛАГЕНА*
}

\author{
В.И. ФИСИНИН 1 , В.С. ЛУКАШЕНКО ${ }^{1} \bowtie$, И.П. САЛЕЕВА ${ }^{1}$, В.Г. ВОЛИК ${ }^{2}$, \\ Д.Ю. ИСМАИЛОВА², Е.А. ОВСЕЙЧИК 1 Е.В. ЖУРАВЧУК 1
}

В последнее время растет интерес к замещению традиционных источников белка в рационе домашней птицы гидролизатами вторичных продуктов животноводства, в частности птицеводства, где отходы при убое и переработке (перо, кишечник, кровь, головы, ноги, мясокостный остаток) составляют до трети живой массы птицы. Ранее мы разработали двухстадийную технологию получения легкоусвояемых белковых кормовых добавок из вторичных продуктов убоя и переработки птицы на основе ферментативных гидролизатов пера и коллагена костного остатка. В настоящем исследовании впервые доказано, что замещение рыбной муки в рационах бройлеров этими кормовыми добавками обеспечивает быстрое увеличение живой массы, а мясо бройлеров по белковому и аминокислотному профилям, содержанию небелкового, пептидного и остаточного азота, жирнокислотному составу и технологическим свойствам соответствует требуемым показателям. Целью работы была сравнительная оценка качества мяса цыплят-бройлеров кросса Ross 308 при выращивании до 38- и 49-суточного возраста на стандартном (полнорационный комбикорм на основе рыбной муки, I группа) и трех экспериментальных рационах (II группа - замещение рыбной муки ферментативным гидролизатом пера, III - гидролизатом коллагенсодержащего сырья, IV смесью гидролизатов с добавлением 0,2 \% пробиотического препарата Бацелл-М и 0,5 \% пшеничных отрубей). Опыты проводили в условиях вивария (Селекционно-генетический центр «Загорское ЭПХ», Московская обл., 2019 год; группы по $n=35$ ). Установлено, что замещение рыбной муки ферментативным гидролизатом кератинсодержащих отходов повышает живую массу птицы на 8,78-10,89 \% по сравнению с контрольной (p $\leq \mathbf{0 , 0 0 1})$. В грудных мышцах бройлеров содержание пептидного азота в I и IV группах возрастало с $0,07 \%$ в возрасте 38 сут до 0,27 и 0,35\% в возрасте 49 сут. С удлинением периода выращивания число белковых фракций в мясе бройлеров (молекулярные массы от 100 до менее 20 кДа) увеличивалось независимо от рациона птицы. Как в 38-, так и в 49-суточном возрасте и независимо от рациона содержание незаменимых аминокислот изолейцина, лейцина, валина и фенилаланин в грудных мышцах было выше, чем в бедренных. В IV группе (смесь гидролизатов с добавлением пробиотика и пищевых растительных волокон) усвояемость незаменимых аминокислот грудных мышц при более длительном выращивании возросла с $81,78 \%$ (возраст убоя 38 сут) до 90,29\% (возраст убоя 49 сут), что было выше, чем в других группах. Определение биологической ценности мяса показало, что более сбалансированное соотношение незаменимых аминокислот характерно для грудных мышц бройлеров из контрольной группы на 38-е сут (коэффициент различия аминокислотного скора 70,53 \%) и IV группы на 49-е сут (коэффициент различия аминокислотного скора 66,48 \%). В бедренных мышцах наиболее сбалансированное соотношение незаменимых аминокислот отмечено в III и IV группах: в III группе $-59,69 \%$ (38 сут), в IV - 61,43 \% (49 сут). Значительных различий по содержанию жирных кислот в мясе цыпля-бройлеров в зависимости от рациона питания птицы мы не установили. Таким образом, полученные результаты свидетельствуют, что применение новых кормовых добавок из ферментативных гидролизатов пера и коллагена в рационах цыплят-бройлеров позволяет получать мясо птицы с требуемыми показателями качества.

Ключевые слова: цыплята-бройлеры, кормовые добавки, перо, коллаген, ферментативные гидролизаты, живая масса, качество мяса, аминокислотный скор, жирные кислоты, эссенциальные нутриенты, технологические свойства.

Мясная продуктивность и качество мяса цыплят-бройлеров во многом зависят от пищевой ценности и структуры рационов (1-5). Состав рациона может существенно изменять процессы пищеварения у сельскохозяйственной птицы, при этом на качество мяса (6-10) в наибольшей степени наряду с зерновым ингредиентом кормов - влияют белки животного происхождения $(5,11-14)$.

Современные высокопродуктивные кроссы мясной птицы очень требовательны к сбалансированным кормовым рационам, поэтому реализация

\footnotetext{
* Работа была выполнена при поддержке Российского научного фонда (Проект № 17-16-01028). 
генетического потенциала цыплят-бройлеров возможна лишь при выращивании на комбикорме с полным набором незаменимых аминокислот, содержащихся в компонентах животного происхождения $(15,16)$. В кормлении птицы также важно использование пробиотиков (17-19) и пребиотиков для повышения переваримости и усвояемости питательных веществ комбикорма $(20,21)$. Рекомендуемые в России нормы суточной потребности птицы по содержанию белка и аминокислот были определены для хорошо перевариваемых кукурузно-соевых комбикормов, где в качестве источника белка животного происхождения использовалась рыбная мука. Но в настоящее время в состав кормосмесей для птицы включают ингредиенты с относительно низкой доступностью питательных веществ - пшеницу, ячмень, подсолнечный шрот, мясокостную муку, а рыбная мука (14, $22,23)$ остается дорогостоящим и дефицитным компонентом. Как следствие, может снижаться интенсивность прироста, мясная продуктивность и качество мяса.

В птицеводстве отходы при убое и переработке (перо, кишечник, кровь, головы, ноги, мясокостный остаток) составляют до 25-30 \% от живой массы птицы. Это один из источников животного белка $(24,25)$. При механической обвалке куриных тушек или их частей 27-40 \% составляет костный остаток с содержанием кости 15-20 \%, полноценных белков - 25-30\%, соотношением золы и белка 0,7 ; большая часть белка и минеральных веществ находится в костной ткани, а влага и жир - в мякотной $(26,27)$.

В последнее время растет интерес к замещению традиционных источников белка в рационе домашней птицы гидролизатами вторичных продуктов животноводства (28-30), в том числе птицеводства (31-33). Отметим, что внимание к этим методам обусловлено и тем, что содержащиеся в гидролизатах пептиды могут проявлять функциональную (регуляторную) и биологическую (противомикробную, антиоксидантную, антигипертензивную и иммуномодулирующую) активность $(34,35)$.

Ранее мы разработали двухстадийную технологию получения легкоусвояемых белковых кормовых добавок из вторичных продуктов убоя и переработки птицы на основе ферментативных гидролизатов пера и коллагена костного остатка (переваримость протеина соответственно до 89 и 84 \%) $(28,32)$ и предложили рецептуры рационов для цыплят-бройлеров. В настоящем исследовании впервые доказано, что при применении этих кормовых добавок увеличение живой массы бройлеров происходит быстрее, а мясо по качеству (белковый и аминокислотный профили, содержание небелкового, пептидного и остаточного азота, жирнокислотный состав, технологические свойства) соответствует требуемым показателям.

Целью работы была оценка качества мяса бройлеров, выращенных на стандартном и трех разработанных экспериментальных рационах на основе ферментативных гидролизатов пера и коллагена.

Методика. Для приготовления новых кормовых добавок использовали в качестве кератинсодержащего сырья перо потрошеных бройлеров с производственной линии, в качестве коллагенсодержащего - костный остаток после механической обвалки; сырье обрабатывали в две стадии (гидротермический гидролиз в тонком слое и ферментативный гидролиз).

Исследования проводили на четырех группах цыплят-бройлеров (Gallus gallus L.) кросcа Ross 308 в возрасте 38 и 49 сут (группы по $n=35$ ) (напольное содержание на подстилке согласно регламенту для кросса, виварий селекционно-генетического центра «Загорское ЭПХ» ФНЦ ВНИТИП РАН, Московская обл., 2019 год). В рационе I группы (контроль) источником протеина была рыбная мука, во II группе ее заменяли соответ- 
ствующим по содержанию белка количеством ферментативного гидролизата пера, в III - ферментативного гидролизата коллагена, в IV - смесью ферментативных гидролизатов пера и коллагена с добавлением 0,2 \% пробиотического препарата Бацелл-М (ОOО «Биотехагро», Россия) и 0,5 \% растительных пищевых волокон (пшеничные отруби).

Для аналитических исследований использовали мясо грудки и бедра 38- и 49-суточных бройлеров.

Для определения водо- и солерастворимых белков 10 г измельченной навески мяса (грудка, бедро) заливали 60 мл дистиллированной воды (или $3,5 \%$ раствором $\mathrm{NaOH}$ ), через 10 мин центрифугировали при 2500 об/мин в течение 10 мин. Надосадочную жидкость сливали в мерную колбу объемом 250 мл. Процедуру повторяли 3 раза, сливая надосадочную жидкость в ту же колбу. Объем доводили до 250 мл водой (или 3,5\% $\mathrm{NaOH}$ ), 50 мл полученного центрифугата и 50 мл 20 \% трихлоруксусной кислоты (ТХУ) перемешивали, оставляли на 40 мин и фильтровали через бумажный фильтр. Осадок на фильтре промывали 10 \% ТХУ и водой. Фильтр с осадком помещали в пробирку для сжигания. Количество азота определяли по методу Кьельдаля.

Для определения щелочерастворимых белков 5 г измельченной навески мяса (грудка и бедро) заливали 50 мл 0,1 н. $\mathrm{NaOH}$, перемешивали, оставляли на 16-18 ч и центрифугировали 10 мин при 2500 об/мин. Надосадочную жидкость сливали в мерную колбу объемом 250 мл. Процедуру повторяли еще 2 раза. Объем центрифугата доводили до 250 мл 0,1 н. $\mathrm{NaOH}$. Аликвоту экстракта объемом 25 мл помещали в пробирку для сжигания, определяли белки по Кьельдалю.

При определении небелкового и остаточного азота 2 г измельченной навески мяса (грудка и бедро) заливали 20 мл дистиллированной воды, перемешивали, оставляли на 10-15 мин, надосадочную жидкость фильтровали через бумажный фильтр в мерную колбу (100 мл), процедуру повторяли еще 3 раза. Объем фильтрата доводили до 100 мл водой, к 30 мл фильтрата добавляли 30 мл 20 \% ТХУ, перемешивали и фильтровали через бумажный фильтр. Аликвоту объемом 25 мл помещали в пробирку для сжигания и определяли остаточный азот по Кьельдалю. Осадок на фильтре также сжигали и определяли небелковый азот по Кьельдалю.

Содержание сырого протеина определяли по ISO 5983-2:2009, концентрацию водородных ионов (рН) - по ISO 2917-749.

Фракционный состав белков исследовали методом одномерного электрофореза в полиакриламидном геле в присутствии додецилсульфата натрия. В микроцентрифужные пробирки отбирали по 50 мкл экстрактов проб, добавляли 50 мкл солюбилизирующего раствора (глицерин $10 \%, \beta$ меркаптоэтанол, 0,02 \% бромфеноловый синий, 0,5 M Трис-HCl, 2 \% SDS) и выдерживали в термостате 5 мин при $95{ }^{\circ} \mathrm{C}$. Надосадочную жидкость, полученную после центрифугирования (Eppendorf 5402R, «Eppendorf», Германия; 10000 об/мин, 7 мин), использовали для разделения методом денатурирующего электрофореза в 12,5 \% полиакриламидном геле (PAGE) в присутствии $0,1 \%$ SDS с использованием электрофоретической камеры (VE10 , ООО «Компания Хеликон», Россия) при постоянной силе тока и напряжении 60 В в концентрирующем геле и 130 В в разделяющем геле в течение 2,5 ч. В качестве стандарта использовали Thermo Scientific ${ }^{\text {тм }}$ PageRuler $^{\mathrm{TM}}$ Unstained Broad Range Protein Ladder (смесь из 11 белков с молекулярными массами 250, 150, 100, 70, 50, 40, 30, 20, 15, 10 и 5 кДа, «Thermo Scientific», США). 
При определении аминокислотных профилей образцы мяса (50 г) измельчали на гомогенизаторе BUCHI Mixer B-400 («BÜCHI Labortechnik AG», Германия), высушивали в сушильном шкафу и обезжиривали в аппарате Сокслета. Пробоподготовку а также окисление цистина (цистеина) и метионина до цистеиновой кислоты и метионинсульфона проводили по ГОСТ 32195 (ISO13903). Навеску 10,0土0,1 мг предварительно высушенного и обезжиренного образца подвергали гидролизу с концентрированной соляной и пропионовой кислотами в соотношении 50:50 в течение 18 ч при температуре $110{ }^{\circ} \mathrm{C}$ в термоблоке для гидролиза. Полученный раствор упаривали досуха на роторном испарителе. Затем в колбу добавляли $1 \mathrm{~cm}^{3}$ буфера с рН 2,2 и количественно переносили в виалу. Предколоночную дериватизацию проводили в автосамплере системы ВЭЖХ с использованием ортофталевого альдегида (ОРА) для первичных аминокислот и 9-фторметилхлорформиата (FMOC) для вторичных аминокислот. Соотношение дериватов к отобранному объему пробы 1:10.

Анализ общих аминокислот выполняли методом высокоэффективной жидкостной хроматографии (ВЭЖХ) на колонке с обращенной фазой (Agilent 1260 Infinity LC, колонка ZORBAX C18 PA, 3,5 мкм 4,6×150 мм, «Agilent Technologies», США). Хроматографическое деление осуществляли в режиме градиентного элюирования в течение 25 мин (для первичных аминокислот $\lambda=338$ нм, для вторичных $-\lambda=262$ нм; элюент А - ацетонитрил: метанол:вода 45:45:10, элюент В - 10 мМ Na2HPO4 и 10 мМ $\left.\mathrm{Na}_{2} \mathrm{~B}_{4} \mathrm{O}_{7}, \mathrm{pH} 8,2\right)$.

Свободные формы аминокислот экстрагировали разбавленной соляной кислотой по ГОСТ 32195-2013 (ISO 13903:2005). Экстрагированные вместе с аминокислотами азотистые макромолекулы осаждали сульфосалициловой кислотой и отфильтровывали. Фильтрат подкисляли до рН 2,2. Аминокислоты разделяли ионообменной хроматографией, проводили реакцию с нингидрином и определяли их содержание фотометрическим детектированием при $\lambda=570$ нм.

Жирнокислотный состав мяса определяли методом газовой хроматографии в модификации ВНИИМП (36). Использовали жир, полученный экстракцией эфиром в аппарате Сокслета в течение 4 ч из подкожной жировой клетчатки и абдоминальный жир тушек птицы. Навеску образца (110 г) обрабатывали в течение 3-24 ч смесью 10 мл хлороформа с 10 мл метанола по модифицированному методу Фолча в присутствии $1 \% \mathrm{KCl}$ для растворения липидных компонентов, фильтровали через бумагу и упаривали досуха. Затем 0,01 г остатка смешивали с 3 мл $15 \%$ раствора ацетилхлорида в метаноле, выдерживали в течение 2 ч про $100{ }^{\circ} \mathrm{C}$ и добавляли КОН в метаноле до рН 5,0-6,0. К смеси приливали 3 мл насыщенного раствора $\mathrm{NaCl}$ и 3 мл гексана, оставляли на 3-5 мин и отбирали для анализа 0,2 мл из прозрачного гексанового слоя, содержащего метиловые эфиры жирных кислот.

Полученные метиловые эфиры анализировали на газовом хроматографе Agilent 7890 («Agilent Technologies», США) с пламенно-ионизационным детектором и капиллярной колонкой HP-Innowax $60 \mathrm{~m} \times 0,32 \mathrm{~mm} \times 0,5 \mu \mathrm{m}$ в токе азота. Градиент температуры от 100 до $260^{\circ} \mathrm{C}\left(10^{\circ} \mathrm{C} /\right.$ мин $)$. Объем проб 1 мкл, смешение потока газов 1:100, температура детектора $250 \ldots 300{ }^{\circ} \mathrm{C}$. Использовали смесь стандартов метиловых эфиров жирных кислот Supelco ${ }^{\circledR} 37$ Component («Sigma-Aldrich», США) с автоматическим расчетом содержания 
Влагосвязывающую способность определяли методом Грау-Хамма в модификации Журавской (37).

При оценке биологической ценности белков использовали коэффициент различия аминокислотного скора испытуемого белка (КРАС, \%), который рассчитывают по формуле:

$$
\mathrm{KPAC}=\frac{\sum_{j=1}^{N} \Delta \mathrm{PAC}}{n} \times 100 \%,
$$

где $\triangle$ РАС - различие аминокислотного скора аминокислоты, который определяется по формуле: $\Delta \mathrm{PAC}=\mathrm{C}_{i}-\mathrm{C}_{\min }\left(\mathrm{C}_{i}-\right.$ избыток скора $i$-й незаменимой аминокислоты, \%; $\mathrm{C}_{\min }-$ минимальный из скоров незаменимой аминокислоты исследуемого белка по отношению к эталону, \%); $n-$ число незаменимых аминокислот. Показатель биологической ценности (БЦ) определяли по формуле: БЦ, \%= $100 \%$ - КРАС.

Статистическую обработку результатов проводили с использованием пакета программ Statistica 10.0 («StatSoft, Inc.», США). Результаты представлены в виде взвешенного среднего значение $M$ со стандартным отклонением $( \pm \mathrm{SD})$. Достоверность различий средних величин, удовлетворяющих условиям нормального распределения и равенству дисперсий, оценивали методом однофакторного дисперсионного анализа (ANOVA) с применением критерия Дункана. Критический уровень значимости нулевой статистической гипотезы (р) принимали равным 0,05.

Результаты. Наибольшую живую массу имели цыплята-бройлеры из II группы, потреблявшие рацион с ферментативным гидролизатом пера: в среднем у петушков и курочек в 38-суточном возрасте она составила 2391 и 2183 г, что на $8,78 \%(\mathrm{p} \leq 0,01)$ и $9,70 \%$ ( $\leq \leq 0,001)$ выше, чем у сверстников из контрольной группы. К 49-м сут живая масса петушков и курочек также была на 9,35\% (p $\leq 0,001)$ и 10,89 \% (p $\leq 0,001)$ выше, чем в контроле. В III и IV группах в эти сроки птица по живой массе превосходила контрольную соответственно на 1,81 и 2,35 \% и на 3,87 и 4,96\%. Вероятно, ускоренный прирост живой массы связан с тем, что при обработке сырья, включая его ферментацию, в гидролизатах повышается содержание свободных пептидов и аминокислот. Известно, что использование легкодоступного гидролизованного протеина повышает эффективность конверсии корма.

Изменение состава белковых фракций мяса в период выращивания птицы отражает таблица 1.

1. Белковые фракции и содержание азота в мясе цыплят-бройлеров (Gallus gallus L.) кросса Ross 308 при использовании в рационах ферментативных гидролизатов пера и коллагена $(n=35, M \pm \mathrm{SD}$, виварий селекционно-генетического центра «Загорское ЭПХ» ФНЦ ВНИТИП РАН, Московская обл., 2019 год)

\begin{tabular}{|c|c|c|c|c|c|c|c|}
\hline \multirow{2}{*}{ Группа } & \multicolumn{4}{|c|}{ Белок, \% } & \multicolumn{3}{|c|}{ Азот, \% } \\
\hline & $\mathrm{BP}$ & $\mathrm{CP}$ & ЩР & общий & пептидный & остаточный & небелковый \\
\hline \multicolumn{8}{|c|}{ 38-с у т о ч н ы е б р ой ле р ы } \\
\hline \multicolumn{8}{|c|}{ Грудные мышцы } \\
\hline I (контроль) & $3,06 \pm 0,05$ & $2,63 \pm 0,05$ & $17,0 \pm 0,1$ & $22,9 \pm 1,8$ & $0,07 \pm 0,01$ & $0,14 \pm 0,03$ & $0,21 \pm 0,03$ \\
\hline II & $2,75 \pm 0,05$ & $2,31 \pm 0,05$ & $16,3 \pm 0,2$ & $22,4 \pm 1,8$ & $0,25 \pm 0,03$ & $0,02 \pm 0,01$ & $0,27 \pm 0,03$ \\
\hline III & $2,75 \pm 0,05$ & $2,81 \pm 0,05$ & $17,8 \pm 0,1$ & $24,3 \pm 1,9^{*}$ & $0,20 \pm 0,02$ & $0,02 \pm 0,01$ & $0,22 \pm 0,02$ \\
\hline IV & $1,55 \pm 0,10$ & $2,19 \pm 0,05$ & $15,8 \pm 0,1$ & $20,2 \pm 1,6$ & $0,07 \pm 0,01$ & $0,14 \pm 0,03$ & $0,21 \pm 0,03$ \\
\hline \multicolumn{8}{|c|}{ Бедренные мышцы } \\
\hline I (контроль) & $2,31 \pm 0,05$ & $1,94 \pm 0,05$ & $14,9 \pm 0,1$ & $19,7 \pm 3,0$ & $0,06 \pm 0,01$ & $0,10 \pm 0,03$ & $0,16 \pm 0,02$ \\
\hline II & $1,94 \pm 0,05$ & $1,69 \pm 0,05$ & $15,7 \pm 0,2$ & $19,9 \pm 3,0$ & $0,19 \pm 0,02$ & $0,02 \pm 0,01$ & $0,21 \pm 0,01$ \\
\hline III & $2,44 \pm 0,05$ & $1,75 \pm 0,10$ & $15,9 \pm 0,1$ & $20,9 \pm 1,7$ & $0,14 \pm 0,01$ & $0,02 \pm 0,01$ & $0,16 \pm 0,03$ \\
\hline IV & $2,56 \pm 0,05$ & $2,00 \pm 0,10$ & $14,3 \pm 0,1$ & $19,3 \pm 1,5$ & $0,23 \pm 0,03$ & $0,02 \pm 0,01$ & $0,25 \pm 0,02$ \\
\hline
\end{tabular}


49-с у т о ч н ы е б о йл е ры Грудные мышцы

$\begin{array}{lllllllr}\text { I (контроль) } & 3,13 \pm 0,05 & 0,69 \pm 0,05 & 17,9 \pm 0,2 & 21,9 \pm 1,8 & 0,27 \pm 0,02 & 0,03 \pm 0,01 & 0,30 \pm 0,03 \\ \text { II } & 2,00 \pm 0,10 & 0,63 \pm 0,05 & 19,0 \pm 0,2 & 23,0 \pm 1,8 & 0,35 \pm 0,01 & 0,03 \pm 0,01 & 0,38 \pm 0,03 \\ \text { III } & 2,44 \pm 0,05 & 0,44 \pm 0,05 & 20,8 \pm 0,1 & 24,0 \pm 1,9 & 0,24 \pm 0,02 & 0,03 \pm 0,01 & 0,27 \pm 0,02 \\ \text { IV } & 3,44 \pm 0,05 & 0,63 \pm 0,05 & 18,0 \pm 0,2 & 23,1 \pm 1,8 & 0,35 \pm 0,03 * & 0,04 \pm 0,01 & 0,39 \pm 0,03 \\ & & \text { Бедренные } \text { мышиы } \\ \text { I (контроль) } & 2,13 \pm 0,05 & 0,50 \pm 0,05 & 15,7 \pm 0,1 & 19,0 \pm 2,8 & 0,31 \pm 0,01 & 0,03 \pm 0,01 & 0,34 \pm 0,03 \\ \text { II } & 2,25 \pm 0,05 & 0,69 \pm 0,05 & 14,8 \pm 0,1 & 18,6 \pm 2,8 & 0,29 \pm 0,01 & 0,03 \pm 0,01 & 0,32 \pm 0,02 \\ \text { III } & 2,56 \pm 0,05 & 0,69 \pm 0,05 & 15,8 \pm 0,2 & 20,2 \pm 1,6 & 0,37 \pm 0,02 & 0,03 \pm 0,01 & 0,40 \pm 0,03 \\ \text { IV } & 2,88 \pm 0,05 & 0,69 \pm 0,05 & 14,0 \pm 0,2 & 17,8 \pm 2,7 & 0,38 \pm 0,02 & 0,02 \pm 0,01 & 0,40 \pm 0,03\end{array}$

П р и м е а н и е. Описание групп см. в разделе «Методика». ВР - водорастворимый, СР - солерастворимый, ЩР - щелочерастворимый.

* Различия с соответствующим контролем статистически значимы при $\mathrm{p} \leq 0,05$.

Содержание белков в мышечной ткани служит показателем пищевой ценности мяса (суточная потребность в белке для взрослого человека составляет 110-160 г, в том числе около 60 \% белков животного происхождения). Белки различаются по аминокислотному составу, строению, растворимости и биологическим функциям. В зависимости от условий экстракции выделяют разные группы белков: водорастворимые (в основном саркоплазматические белки - миоген, глобулин, миоглобин, а также нуклеопротеиды); солерастворимые (в основном миофибриллярные белки - миозин, актин, актомиозин). М. Eady с соавт. (38) проводили экстракцию солерастворимых и водорастворимых белков, используя буферы с различными значениями $\mathrm{pH}-5,4 ; 6,4 ; 6,9 ; 7,2 ; 7,5 ; 8,0$ и 9,0. Измеряли концентрацию белка в экстрактах и проводили SDS-PAGE анализ. Данные показывают, что посмертное старение и рН буфера для экстракции влияют как на общее количество, так и на состав миофибриллярных и саркоплазматических белков, которые могут быть извлечены из филе грудки бройлеров. Выделены также регуляторные белки тропомиозин, тропонин и щелочерастворимые (в основном белки стромы, в том числе коллаген, эластин, а также гликопротеиды - муцин и мукоид) (39).

В нашем опыте (см. табл. 1) в период с 38-х по 49-е сут жизни у бройлеров снижалась доля солерастворимых белков как в грудных, так и в бедренных мышцах при сохранении количественного соотношения водо- и щелочерастворимой белковых фракций. Однако нужно отметить, что миоген и миоглобулин, которые классифицируются как водорастворимые белки, частично экстрагируются солевым раствором, а значительная часть водо- и солерастворимых белков - щелочью. Возможно, соотношение водо-, солеи щелочерастворимых белков в мясе птицы - недостаточно объективная характеристика возрастных изменений.

Содержание пептидного азота в мясе цыплят-бройлеров изменялось с возрастом птицы (см. табл. 1). В I (контроль) и IV группах на 38-е сут этот показатель составлял $0,07 \%$, на 49-е сут - повышался в контроле до 0,27 \% $(\mathrm{p} \leq 0,05)$, в IV группе - до $0,35 \%$ ( $\mathrm{p} \leq 0,05)$. Аналогичную тенденцию отмечали в бедренных мышцах, но в этом случае различия были статистически недостоверны. По остаточному и небелковому азоту изменения были статистически значимы (см. табл. 1).

Оценка технологических свойств мяса (рН и влагосвязывающая способность, ВСС) при выращивании птицы на стандартном и экспериментальных рационах не выявила принципиальных различий по величине рН между грудными и бедренными мышцами в оба возрастных периода: все изученные образцы соответствовали значению рН 6,0-6,8, принятому для мяса птицы (табл. 2). Выращивание до 49-суточного возраста повышало 
ВСС в сравнении с таковой у 38-суточной птицы независимо от рациона.

2. рН и влагосвязывающая способность (ВСС) мяса цыплят-бройлеров (Gallus gallus L.) кросса Ross 308 при использовании в рационах ферментативных гидролизатов пера и коллагена $(n=35, M \pm \mathrm{SD}$, виварий селекционно-генетического центра «Загорское ЭПХ» ФНЦ ВНИТИП РАН, Московская обл., 2019 год)

\begin{tabular}{|c|c|c|c|c|}
\hline \multirow{2}{*}{ Группа } & \multicolumn{2}{|c|}{$\mathrm{pH}$} & \multicolumn{2}{|c|}{$\mathrm{BCC}, \%$} \\
\hline & в возрасте 38 сут & в возрасте 49 сут & в возрасте 38 сут & в возрасте 49 сут \\
\hline \multicolumn{5}{|c|}{ Гр удн ы е $\quad$ м ыш цы } \\
\hline I (контроль) & $6,65 \pm 0,01$ & $6,69 \pm 0,01$ & $53,75 \pm 0,22$ & $54,53 \pm 0,20$ \\
\hline II & $6,38 \pm 0,01$ & $6,18 \pm 0,01$ & $52,41 \pm 0,24$ & $60,86 \pm 0,27$ \\
\hline III & $6,61 \pm 0,01$ & $6,33 \pm 0,01$ & $60,23 \pm 0,27^{*}$ & $63,83 \pm 0,26^{*}$ \\
\hline IV & $6,52 \pm 0,01$ & $6,87 \pm 0,01$ & $62,18 \pm 0,29^{*}$ & $64,66 \pm 0,26^{*}$ \\
\hline \multicolumn{5}{|c|}{ Бе д ренны е мышц ц } \\
\hline I (контроль) & $6,71 \pm 0,01$ & $6,52 \pm 0,01$ & $53,83 \pm 0,29$ & $54,21 \pm 0,18$ \\
\hline II & $6,80 \pm 0,01$ & $6,51 \pm 0,01$ & $53,51 \pm 0,27$ & $60,15 \pm 0,20$ \\
\hline III & $7,01 \pm 0,01$ & $6,79 \pm 0,01$ & $60,90 \pm 0,26^{*}$ & $62,23 \pm 0,20^{*}$ \\
\hline IV & $6,71 \pm 0,01$ & $6,52 \pm 0,01$ & $53,83 \pm 0,29$ & $54,21 \pm 0,18$ \\
\hline
\end{tabular}

Подобный эффект описан у 60-, 90-, 120-, 150- и 180-суточных бройлеров Da Heng: с возрастом потери стекания мяса грудки снижались (40). Влияние сроков убоя авторы связывают с возрастными особенностями морфологии мышечных волокон (диаметр, площадь поперечного сечения миофибрилл, плотность их укладки в мышечном волокне). Большая масса тела и масса грудки цыплят обусловлена большим диаметром и площадью миофибры, меньшей плотности миофибры у старых птиц, чем у молодых. Авторы отмечали влияние возраста на все мясные качественные характеристики мышц куриной грудки $(\mathrm{p}<0,05)$ : часто наблюдали повышение $\mathrm{pH}$, снижение ВСС, бо́льшую силу сдвига, более темное и красное мясо. Биохимические и молекулярные механизмы, лежащие в основе наблюдаемой зависимости качества мяса от характеристики мышц еще требуют изучения (40).

В нашем опыте наибольшие значения ВСС были характерны для образцов белого и красного мяса цыплят-бройлеров в III группе, получавшей ферментативный гидролизат коллагена $(\mathrm{p} \leq 0,05)$, и в IV группе, которую кормили смесью ферментативных гидролизатов пера и коллагена с добавлением $0,2 \%$ пробиотического препарата Бацелл-М ( $\mathrm{p} \leq 0,05)$. Отметим, что способность сохранять влагу в процессе хранения и переработки определяет пригодность мясного сырья для изготовления широкого ассортимента продуктов (за исключением сырокопченых и сыровяленых изделий). Снижение такой способности связано с процессами денатурации белков (41). В. Bowker с соавт. (41) отмечали, что различия в сохранении влаги в филе грудки бройлеров не были обусловлены различиями в денатурации миофибриллярных белков, и предположили, что денатурация саркоплазматических белков на миофибриллы может влиять на сохранение влаги в мясе грудки. Отмеченное нами повышение ВСС свидетельствует об улучшении технологических свойств мяса бройлеров при выращивании на экспериментальных рационах.

Одно- и двумерный денатурирующий электрофорез белков мяса в полиакриламидном геле широко используют как способ сравнения протеомных профилей при воздействии различных факторов. Полученные нами результаты фракционирования белков в исследуемых образцах мяса 

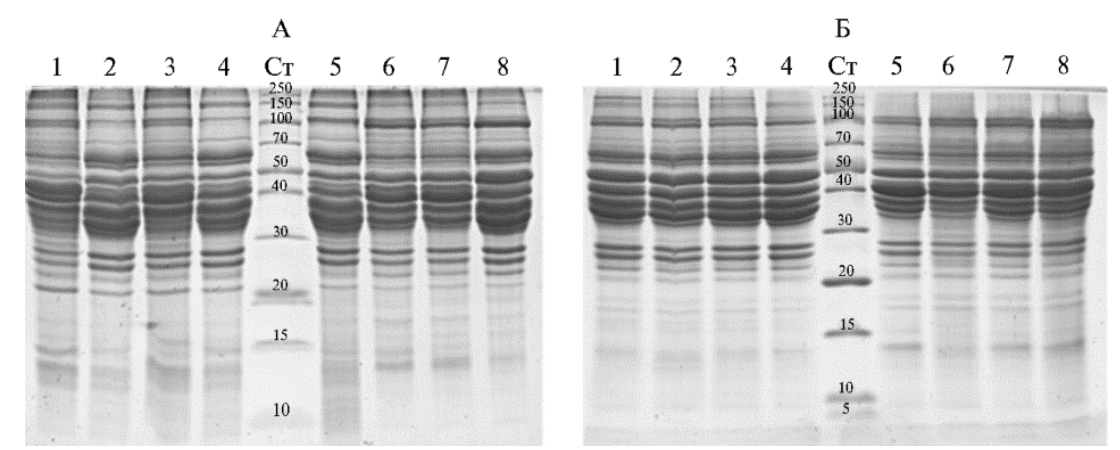

Рис. 1. 1D-электрофореграммы (SDS-PAGE) образцов мяса 38-суточных (А) и 49-суточных (Б) цыплят-бройлеров (Gallus gallus L.) кросса Ross 308 при использовании в рационах ферментативных гидролизатов пера и коллагена: 1 - бедро (I группа, контроль); 2 - бедро (II группа); 3 - бедро (III группа); 4 - бедро (IV группа); 5 - грудка (I группа, контроль); 6 - грудка (II группа); 7 - грудка (III группа); 8 - грудка (IV группа). Ст - стандарт молекулярных масс (Thermo Scientific ${ }^{\mathrm{TM}}$ PageRuler ${ }^{\mathrm{TM}}$ Unstained Broad Range Protein Ladder, 250, 150, 100, 70, 50, 40, 30, 20, 15, 10 и 5 кДа, «Thermo Scientific», США) (виварий селекционно-генетического центра «Загорское ЭПХ» ФНЦ «ВНИТИП» РАН, Московская обл., 2019 год).

3. Число белковых фракций, идентифицированных методом 1D SDS-PAGE электрофореза в образцах мяса 38- и 49-суточных цыплят-бройлеров (Gallus gallus L.) кросса Ross 308, при использовании в рационах ферментативных гидролизатов пера и коллагена (виварий селекционно-генетического центра «Загорское ЭПХ» ФНЦ ВНИТИП РАН, Московская обл., 2019 год)

\begin{tabular}{|c|c|c|c|c|c|c|c|c|}
\hline \multirow{2}{*}{$\begin{array}{l}\text { Диапазон молеку- } \\
\text { лярных масс, кДа }\end{array}$} & \multicolumn{2}{|c|}{ I (контроль) } & \multicolumn{2}{|c|}{ II } & \multicolumn{2}{|c|}{ III } & \multicolumn{2}{|c|}{ IV } \\
\hline & грудка & бедро & грудка & бедро & грудка & бедро & грудка & бедро \\
\hline \multicolumn{9}{|c|}{ 38-суточные бройлеры } \\
\hline$>100$ & 6 & 7 & 7 & 5 & 6 & 7 & 7 & 5 \\
\hline $100-40$ & 11 & 12 & 12 & 10 & 11 & 12 & 12 & 10 \\
\hline $39-20$ & 10 & 10 & 9 & 9 & 9 & 10 & 10 & 9 \\
\hline$<20$ & 17 & 14 & 11 & 12 & 11 & 14 & 11 & 12 \\
\hline Всего & 44 & 43 & 39 & 36 & 37 & 43 & 40 & 36 \\
\hline \multicolumn{9}{|c|}{ 49-суточные бройлеры } \\
\hline$>100$ & 6 & 5 & 6 & 7 & 6 & 7 & 6 & 7 \\
\hline $100-40$ & 12 & 11 & 12 & 11 & 12 & 11 & 14 & 14 \\
\hline $39-20$ & 10 & 10 & 9 & 11 & 9 & 11 & 14 & 9 \\
\hline$<20$ & 14 & 10 & 11 & 12 & 11 & 12 & 14 & 12 \\
\hline Всего & 42 & 36 & 38 & 41 & 38 & 41 & 48 & 43 \\
\hline
\end{tabular}

На 38-е сут наибольшее число белковых фракций отмечали в образцах мяса цыплят-бройлеров в I и III (рацион с ферментативным гидролизатом коллагена) группах, причем в основном это были низкомолекулярные пептиды (см. рис. 1, табл. 3). На 49-е сут число фракций было максимальным в IV группе (грудные мышцы), при этом доля фракций с молекулярной массой менее 40 кДа увеличилась на $33 \%$ по сравнению с показателем в возрасте 38 сут. Этот факт представляет интерес, поскольку известно, что многие низкомолекулярные пептиды биологически активны. Так, Y. Hou с соавт. (35) отмечают, что включение некоторых гидролизатов животного белка (например, кишечника свиньи, внутренностей лосося или тканей птицы) или гидролизатов соевого белка в количестве 2-8 \% в рационы на основе кукурузы и соевого шрота может обеспечить желательные темпы роста и эффективность откорма у свиней-отъемышей, телят, птицы в первые сутки жизни. Таким образом, белковые гидролизаты представляются перспективными в оптимизации питания продуктивных животных.

Основная наблюдаемая нами тенденция сводилась к тому, что в контроле общее число белковых фракций с возрастом уменьшалось, а при 
использовании всех экспериментальных рационов - увеличивалось, причем в наибольшей степени в IV группе, получавшей смесь ферментативных гидролизатов пера и коллагена и 0,2 \% пробиотический препарат Бацелл-М (см. рис. 1, табл. 3).

Оценка аминокислотной сбалансированности образцов (рис. 2) при убое на 38-е сут показала максимальные значения для грудных мышц птицы из I группы и для бедренных - из III. В возрасте 49 сут максимальную сбалансированность по аминокислотным профилям отмечали как в грудных, так и в бедренных мышцах бройлеров из IV группы. Представленная диаграмма отражает различия использованных рационов по влиянию на сбалансированность аминокислот в грудных и бедренных мышцах бройлеров (в сочетании и по отдельности), а также в зависимости от возраста (см. рис. 2). Обобщая, можно заключить, что при откорме в течение 38 сут замена рыбной муки гидролизатом коллагена (III группа) позволяет обеспечить лучшую сбалансированность белков бедренных мышц, а при более длительном выращивании (49 сут) показатели сбалансированности повышаются при замене рыбной муки смесью гидролизатов коллагена и пера в сочетании с пробиотиком Бацелл-M (IV группа).

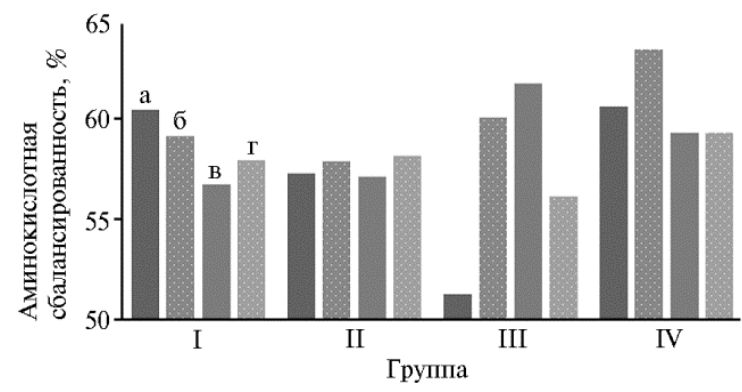

«ВНИТИП» РАН, Московская обл., 2019 год).

Рис. 2. Аминокислотная сбалансированность мяса 38- и 49-суточных цыплят-бройлеров (Gallus gallus L.) кросса Ross 308, при использовании в рационах ферментативных гидролизатов пера и коллагена: а - 38 сут, грудные мышцы, б - 49 сут, грудные мышцы, в - 38 сут, бедренные мышцы, г 49 сут, бедренные мышцы. Отклонения от средних значений $\pm 2 \%$, описание групп см. в разделе «Методика» (виварий селекционно-генетического центра «Загорское ЭПХ» ФНЦ

Оценка полноценности белка обязательна при определении питательности и усвояемости пищевых продуктов и их ингредиентов (42). Так, исследование физико-химических свойств и питательности мяса нового китайского кросса 817 Crossbred chicken в сравнении с коммерческими импортными бройлерами (ААВ) и курами-несушками вывило преимущество нового кросса по питательной ценности мяса (грудка и бедро птицы). У этого кросса во фракции эссенциальных аминокислот преобладающими аминокислотами были лизин и лейцин, а глутаминовая и аспарагиновая кислоты оказались основными во фракции заменимых аминокислот.

Животный белок - один из наиболее концентрированных источников незаменимых аминокислот в рационе человека. Способность улучшать профили эссенциальных аминокислот в мясе птицы изучается у широкого спектра нетрадиционных кормовых ингредиентов. Например, Р. Hašć́k c coавт. (43) обнаружили более высокую концентрацию тирозина $(\mathrm{p} \leq 0,05)$ в мышцах грудки в группе, получавшей корм с добавлением пробиотиков и экстракта прополиса. Учитывая состав аминокислот и относительно высокий балл незаменимых аминокислот, мясо грудки цыплят, получавших пробиотик и экстракт прополиса, представляется интересным источником белков с повышенным (p $\leq 0,05)$ содержанием фенилаланина и тирозина $(76,27 \%)$ по сравнению с контрольной группой $(73,49 \%)$.

Оптимизация рационов по незаменимым лимитирующим аминокислотам оказывает прямое воздействие не только на продуктивность и качество мяса птицы, но и на ее иммунитет (11). Отмечали постепенное 
увеличение титра антител против вируса болезни Ньюкасла по мере повышения содержания белка в рационе и энергетической обеспеченности птицы. Предполагается, что лучший прирост массы тела подтверждает здоровье и титр антител. Более того, лучший иммунный ответ, зафиксированный авторами в этом исследовании, может быть обусловлен лучшим использованием питательных веществ, в том числе на формирование иммунного ответа (11).

В нашем опыте расчет скора незаменимых аминокислот показал (табл. 4), что в грудных мышцах у контрольных бройлеров (I группа) лимитирующей аминокислотой был валин в оба срока убоя, во II группе лейцин в возрасте 38 сут, в III - тирозин в оба срока, в IV - тирозин в возрасте 38 сут. В бедренных мышцах в I (контрольной) группе лимитирующей аминокислотой был цистин в оба срока, во II группе - лизин в возрасте 38 сут, в III - валин в оба срока, в IV - валин в возрасте 38 сут и цистин в 49 сут.

4. Скор (\%) незаменимых аминокислот в мясе цыплят-бройлеров (Gallus gallus L.) кросса Ross 308 при использовании в рационах ферментативных гидролизатов пера и коллагена $(n=35$, виварий селекционно-генетического центра «Загорское ЭПХ» ФНЦ ВНИТИП РАН, Московская обл., 2019 год)

\begin{tabular}{|c|c|c|c|c|c|c|c|c|}
\hline \multirow{2}{*}{ Аминокислота } & \multicolumn{4}{|c|}{ В возрасте 38 сут } & \multicolumn{4}{|c|}{ В возрасте 49 сут } \\
\hline & I (контроль) & II & III & IV & I (контроль) & II & III & IV \\
\hline \multicolumn{9}{|c|}{ Гр у д н ы е м ыш ц ы } \\
\hline Треонин & 99,35 & 157,38 & 63,78 & 118,80 & 127,85 & 127,18 & 128,13 & 99,58 \\
\hline Тирозин & 140,48 & 145,57 & 53,70 & 81,78 & 85,35 & 85,09 & 86,96 & 105,39 \\
\hline Цистин & 100,77 & 89,31 & 76,00 & 137,08 & 77,31 & 73,62 & 80,15 & 143,15 \\
\hline Валин & 81,22 & 91,96 & 74,08 & 84,16 & 86,76 & 86,08 & 86,66 & 90,90 \\
\hline Метионин & 133,00 & 115,68 & 99,14 & 126,00 & 112,09 & 110,68 & 111,73 & 131,82 \\
\hline Фенилаланин & 101,49 & 95,32 & 100,11 & 104,35 & 119,70 & 115,16 & 116,00 & 106,46 \\
\hline Изолейцин & 108,08 & 120,53 & 149,18 & 118,80 & 160,95 & 160,88 & 161,45 & 114,73 \\
\hline Лейцин & 109,80 & 72,07 & 121,10 & 113,16 & 127,86 & 129,81 & 130,36 & 90,29 \\
\hline Лизин & 133,38 & 90,09 & 172,09 & 131,42 & 145,29 & 143,87 & 144,69 & 139,31 \\
\hline Триптофан & 99,35 & 157,38 & 177,00 & 277,20 & 127,85 & 127,18 & 166,70 & 216,50 \\
\hline \multicolumn{9}{|c|}{ Бе д р енны е м ыш ц ы } \\
\hline Треонин & 110,13 & 121,85 & 143,55 & 121,75 & 75,00 & 88,70 & 122,53 & 89,90 \\
\hline Тирозин & 136,48 & 131,09 & 174,74 & 137,43 & 105,26 & 123,87 & 163,57 & 124,57 \\
\hline Цистин & 70,08 & 127,54 & 92,00 & 115,62 & 145,77 & 74,46 & 159,92 & 77,77 \\
\hline Валин & 75,94 & 90,46 & 85,16 & 77,72 & 73,68 & 77,42 & 68,32 & 78,66 \\
\hline Метионин & 112,77 & 118,77 & 93,50 & 124,82 & 110,05 & 117,32 & 139,50 & 120,00 \\
\hline Фенилаланин & 98,54 & 77,41 & 104,76 & 106,43 & 106,68 & 95,89 & 89,65 & 97,19 \\
\hline Изолейцин & 97,48 & 89,20 & 92,10 & 117,88 & 128,95 & 112,90 & 100,25 & 113,78 \\
\hline Лейцин & 101,99 & 94,04 & 103,90 & 111,77 & 121,06 & 92,17 & 102,54 & 92,30 \\
\hline Лизин & 119,67 & 71,27 & 111,35 & 130,95 & 156,95 & 106,55 & 125,11 & 105,22 \\
\hline Триптофан & 298,70 & 211,10 & 253,60 & 279,80 & 236,80 & 258,10 & 203,00 & 264,00 \\
\hline
\end{tabular}

В возрасте 38 сут в IV группе, получавшей смесь гидролизатов кератина, коллагена и пробиотик, содержание цистина повышалось на 37$43 \%$ по сравнению с контролем. По содержанию триптофана в грудных мышцах все экспериментальные группы значительно (в 1,9-2,9 раза) превосходили контроль (рацион на основе рыбной муки). В этом же возрасте (38 сут) в бедренных мышцах увеличивалось содержание цистина во II и IV группах (на 65-82 \% выше, чем в контроле), но при откорме до 49 сут его количество снижалось.

Как видно (см. табл. 4), в нашем опыте скоры незаменимых аминокислот варьировали в зависимости от вида образца и рациона, но в целом замена рыбной муки повышала показатели по цистину и триптофану и улучшала сбалансированность мяса грудки и бедра по незаменимым аминокислотам. Тем не менее как в 38-, так и в 49-суточном возрасте содержание изолейцина, лейцина, валина, фенилаланина, отвечающих за рост и развитие мышечной ткани, в грудных мышцах бройлеров было выше, чем 
в бедренных. Известно, что количественный состав аминокислот в бедренных и грудных мышцах различается (44). Полученные нами результаты согласуются, в частности, с данными относительно использования альтернативных белковых кормовых добавок из побочных продуктов переработки птицы, обеспечивающих увеличение темпов роста и эффективность кормового рациона птицы (43).

Усвояемость белков считается их существенной биологической характеристикой. В нашем опыте в случае бедренных мышц усвояемость аминокислот с возрастом птицы увеличилась примерно на $4 \%$, но все же осталась ниже, чем для грудных (табл. 5), хотя накопление незаменимых аминокислот в мышечной ткани бедра было выше на $8 \%$.

5. Усвояемость (\%) незаменимых аминокислот из мяса цыплят-бройлеров (Gallus gallus L.) кросса Ross 308 при использовании в рационах ферментативных гидролизатов пера и коллагена $(n=35$, виварий селекционно-генетического центра «Загорское ЭПХ» ФНЦ ВНИТИП РАН, Московская обл., 2019 год)

\begin{tabular}{l|c|c|c|c}
\hline \multirow{2}{*}{ Группа } & \multicolumn{2}{|c|}{ Грудные мышцы } & \multicolumn{2}{c}{ Бедренные мышцы } \\
\cline { 2 - 5 } & в возрасте 38 сут & в возрасте 49 сут & в возрасте 38 сут & в возрасте 49 сут \\
\hline I (контроль) & 81,22 & 77,31 & 70,08 & 73,68 \\
II & 72,07 & 73,62 & 71,27 & 74,46 \\
III & 53,70 & 80,15 & 75,16 & 68,32 \\
IV & 81,78 & 90,29 & 77,72 & 77,77 \\
\multicolumn{2}{l}{ П р и м е ч а н и е. Описание групп см. в разделе «Методика». } \\
\hline
\end{tabular}

Полноценными считаются белки тех продуктов, в которых скор всех незаменимых аминокислот равен $100 \%$. Аминокислотный скор каждой незаменимой аминокислоты в «идеальном белке» принимают за $100 \%$, а в природном белке продукта либо в суммарном белке рациона определяют процент соответствия. Если скор хотя бы одной аминокислоты менее $100 \%$, то развитие организма задерживается и определяется лимитирующей аминокислотой. Следовательно, белок грудных мышц в первых трех группах не может считаться полноценным. В IV группе усвояемость незаменимых аминокислот грудных мышц в период с 38-х по 49-е сут возросла с 81,78 до 90,29 \%, что выше, чем в других группах. Исходя из принятой точности $5 \%$ и погрешности методов, можно сделать вывод, что на 49-е сут откорма белок грудных мышц в IV группе являлся полноценным. В этой же IV группе усвояемость незаменимых аминокислот из бедренных мышц с возрастом не изменилась $(77,72-77,77$ \%). Единственное изменение заключалось в том, что лимитирующей аминокислотой стал цистин. В целом усвояемость незаменимых аминокислот в IV группе оставалась выше, чем в других группах, независимо от типа образца и возраста убоя.

По результатам проведенных исследований аминокислотного анализа четырех групп откорма птиц были рассчитаны показатели биологической ценности белка мяса птиц (44): аминокислотный скор (АС, \%), коэффициент различия аминокислотного скора (КРАС, \%) (см. табл. 4) и биологическая ценность (БЦ, \%). Чем меньше величина КРАС, тем выше качество белка. Определение биологической ценности грудных и бедренных мышц (табл. 6) показало, что в I и II группах в грудных мышцах на 38-е сут не используется 29,47 и 41,46 \% аминокислот, на 49-е сут - 39,79 и 42,34 \%. B III и IV группах, наоборот, избыток незаменимых аминокислот уменьшался. Так, в 38-суточном возрасте коэффициент различия аминокислотного скора в грудных мышцах составлял соответственно 54,92 и 47,50 \%, а к 49-суточном возрасту доля неиспользуемых незаменимых аминокислот уменьшилась до 41,13 и 33,52 \%. Следовательно, в грудных мышцах более сбалансировано соотношение незаменимых аминокислот в I группе на 
38-е сут (биологическая ценность 70,53 \%) и в IV группе на 49-е сут (биологическая ценность $66,48 \%)$.

6. Показатели биологической ценности (\%) мяса цыплят-бройлеров (Gallus gallus L.) кросса Ross 308 при использовании в рационах ферментативных гидролизатов пера и коллагена $(n=35$, виварий селекционно-генетического центра «Загорское ЭПХ» ФНЦ ВНИТИП РАН, Московская обл., 2019 год)

\begin{tabular}{|c|c|c|c|c|c|c|c|c|}
\hline \multirow{3}{*}{ Группа } & \multicolumn{4}{|c|}{ Грудные мышцы } & \multicolumn{4}{|c|}{ Бедренные мышцы } \\
\hline & \multicolumn{2}{|c|}{ в возрасте 38 сут } & \multicolumn{2}{|c|}{ в возрасте 49 сут } & \multicolumn{2}{|c|}{ в возрасте 38 сут } & \multicolumn{2}{|c|}{ в возрасте 49 сут } \\
\hline & KPAC & БЦ & KPAC & БЦ & KPAC & БЦ & KPAC & БЦ \\
\hline I (контроль) & 29,47 & 70,53 & 39,79 & 60,21 & 52,10 & 47,90 & 52,34 & 47,66 \\
\hline II & 41,46 & 58,54 & 42,34 & 57,67 & 42,00 & 58,00 & 40,28 & 59,72 \\
\hline III & 54,92 & 45,08 & 41,13 & 58,87 & 40,31 & 59,69 & 59,12 & 40,88 \\
\hline IV & 47,50 & 52,51 & 33,52 & 66,48 & 54,70 & 45,30 & 38,57 & 61,43 \\
\hline
\end{tabular}

В бедренных мышцах наблюдалась иная тенденция. В I группе мы не выявили никаких изменений в период с 38-х по 49-е сут откорма. Однако, если сравнить коэффициент различия аминокислотного скора грудных и бедренных мышц, видно, что в бедренных мышцах избыточных незаменимых аминокислот в 1,5 раза больше. Во II группе происходило уменьшение коэффициента различия аминокислотного скора, и этот коэффициент по бедренным мышцам отличался (хотя и незначительно) от коэффициента по грудным мышцам. В ІІІ группе наблюдалась тенденция к увеличению коэффициента различия аминокислотного скора с 40,31 до 59,12 \% по бедренным мышцам, в то время как по грудным происходило уменьшение примерно на такую же величину. B IV группе коэффициент различия аминокислотного скора явно уменьшался: в грудных мышцах с 47,50 \% на 38 -е сут до 33,52 \% на 49-е сут, в бедренных - соответственно с 54,70 до $38,57 \%$. Следовательно, наиболее сбалансированным соотношением незаменимых аминокислот характеризовались бедренные мышцы в III группе $(59,69 \%$ на 38 -е сут) и в IV группе $(61,43 \%$ на 49 -е сут).

Показателем качества мяса птицы также служит содержание жирных кислот, которое может различаться у пород, в зависимости от рационов и добавок $(45,46)$. Результаты определения жирнокислотного состава образцов мяса цыплят, выращенных на разных рационах в течение 38 и 49 сут, показали, что наибольшую долю жирных кислот составляли пальмитиновая (насыщенная/предельная жирная кислота), олеиновая (ненасыщенная $\omega-9$ жирная кислота) и линолевая (ненасыщенная $\omega-6$ жирная кислота), доля соответственно 16,49 и 21,50 \%, 25,63 и 33,57 \% и 32,39 и 45,68 \%. Ненасыщенные жирные кислоты, особенно олеиновая и линолевая, - незаменимые нутриенты для человека. Согласно полученным нами результатам, различия в содержании олеиновой кислоты между группами составили 7,94 \% для четырех групп 38-суточных бройлеров и 2,49 \% - для 49-суточных. Такие различия в процентном содержании жирных кислот можно объяснить рационами на основе разных источников белка животного происхождения.

Итак, нами установлено, что использование ферментативного гидролизата кератинсодержащего сырья вместо рыбной муки (контроль) в рационах цыплят-бройлеров дает прибавку живой массы на 9-10 \%, использование гидролизата коллагенсодержащего сырья - на 3,80 \%, смеси этих гидролизатов с добавлением пробиотика Бацелл-М - на 4,96 \%. Продленный период выращивания (до 49 сут) повышает водосвязывающую способность (ВСС) мяса бройлеров по сравнению с таковой в 38-суточном возрасте убоя независимо от рациона. Наибольшие показатели ВСС в грудных 
и бедренных мышцах имели цыплята-бройлеры, получавшие гидролизат коллагенсодержащего сырья и смесь ферментативных гидролизатов кератин- и коллагенсодержащего сырья в сочетании с пробиотиком Бацелл-М (ВСС соответственно на 4,3 и 12,4 \% выше, чем в контроле). Соотношение незаменимых аминокислот более сбалансировано в грудных мышцах бройлеров контрольной группы на 38-е сут (биологическая ценность 70,53 \%) и группы, получавшей смесь ферментативных гидролизатов в сочетании с пробиотиком Бацелл-М, на 49-е сут $(66,48 \%)$. В этой же группе усвояемость незаменимых аминокислот грудных мышц на 38-е сут достигла показателя в контрольной группе, а к 49-м сут превысила его на 16,8 \%. Усвояемость незаменимых аминокислот бедренных мышц практически во всех опытных группах превышала показатели в контрольной группы (у бройлеров, получавших смесь ферментативных гидролизатов в сочетании с пробиотиком Бацелл-М, - на 10,9 \%). Таким образом, рационы с использованием кормовых белковых добавок из кератин- и коллагенсодержащего сырья могут быть использованы при выращивании цыплят-бройлеров и позволяют получать мясо птицы с требуемыми биологическими и технологическими показателями качества.

\footnotetext{
1 ФНЦ Всероссийский научно-исследовательский и технологический институт птицеводства РАН, 141311 Россия, Московская обл., г. Сергиев Посад, ул. Птицеградская, 10, e-mail: fisinin@land.ru, lukashenko@vnitip.ru $\bowtie$, saleeva@vnitip.ru, ovseychik@vnitip.ru, evgeniy_20.02@mail.ru;

${ }^{2}$ Всероссийский НИИ птицеперерабатывающей промышленности - филиал

ФНЦ Всероссийский научно-исследовательский

и технологический институт птицеводства РАН,

141552 Россия, Московская обл., Солнечногорский р-н,

п/о Ржавки, ВНИИПП,

e-mail: volik@dinfo.ru, dilaramis08@mail.ru
}

Поступила в редакцию 2 декабря 2019 года

\title{
THE EFFECTS OF ENZYMATIC HYDROLYSATES OF FEATHERS AND COLLAGEN IN DIETS FOR BROILER CHICKS (Gallus gallus L.) ON MEAT QUALITY
}

\author{
V.I. Fisinin', V.S. Lukashenko ${ }^{\bowtie}$, I.P. Saleeva1, V.G. Volik², D.Yu. Ismailova², \\ E.A. Ovseychik', E.V. Zhuravchuk ${ }^{1}$
}

\begin{abstract}
${ }^{1}$ Federal Scientific Center All-Russian Research and Technological Poultry Institute RAS, 10, ul. Ptitsegradskaya, Sergiev Posad, Moscow Province, 141311 Russia, e-mail fisinin@land.ru, lukashenko@vnitip.ru ( $₫$ corresponding author), saleeva@vnitip.ru, ovseychik@vnitip.ru, evgeniy_20.02@mail.ru;

${ }^{2}$ All-Russian Research Institute of Poultry Processing Industry - Branch of Federal Scientific Center All-Russian Research and Technological Poultry Institute RAS, 1, Rzhavki, Solnechnogorsk Region, Moscow Province, 141552, e-mail volik@dinfo.ru,dilaramis08@mail.ru

ORCID:

Fisinin V.I. orcid.org/0000-0003-0081-6336

Lukashenko V.S. orcid.org/0000-0002-0107-8235

Saleeva I.P. orcid.org/0000-0002-7446-1593

Volik V.G. orcid.org/0000-0002-1798-2093

The authors declare no conflict of interests

Acknowledgements:

Supported financially by Russian Science Foundation (agreement No. 17-16-01028)

Received December 2, 2019

Ismailova D.Yu. orcid.org/0000-0003-3918-8752

Ovseychik E.A. orcid.org/0000-0002-2312-1388

Zhuravchuk E.V. orcid.org/0000-0002-2951-0659

doi: 10.15389/agrobiology.2021.2.384eng
\end{abstract}

Abstract

The deficit of feed-grade protein for the productive animals and poultry is presently propelling the interest toward the use of the hydrolysates of slaughter wastes as the potential protein sources. The slaughter wastes of poultry (feathers, intestines, blood, heads, shanks, meat-bone residues of the deboning) can mount up to one third of the initial bodyweight. Earlier we have developed the two- 
stage technology of easily digestible protein additives involving the hydrolysis and fermentation of protein from poultry slaughter wastes (primarily keratin from feathers and collagen from meat-bone residue). The study presented is a pioneer evidence that the substitution of these additives for fishmeal in diets for broilers provides more rapid growth and does not deteriorate the protein, fatty and amino acid profiles, concentrations of non-peptide, peptide and residual nitrogen, technological properties of meat. The study was performed in 2019 and aimed at the comparative evaluation of meat quality at 38 and 49 days of age in floor-housed broilers fed standard diet and three experimental diets with these hydrolysates. The broilers (cross Ross-308, 35 birds per treatment) kept in conditions of the Center for Genetics \& Selection "EPH Zagorskoye” (Moscow Province) were allotted to four treatments partially slaughtered at 38 days of age and partially at 49 days. Control treatment 1 was fed a standard broiler diet with fishmeal; in experimental treatments fishmeal was substituted by enzymatic hydrolysate of feathers (treatment 2), enzymatic hydrolysate of collagen (treatment 3), mixture of these two hydrolysates with addition of probiotic Bacell M $(0.2 \%)$, and bran $(0.5 \%)$ as a source of vegetable fiber (treatment 4). It was found that supplementation of diets with the hydrolysates of keratin and collagen significantly improved live bodyweight in broilers by $8.78-10.89 \%$ in compare to control $(\mathrm{p} \leq 0.001)$. The content of peptide nitrogen in breast muscles in treatments 1 and 4 tended to grow with the increase in slaughter age (in treatment 1 from 0.07 at 38 days to $0.27 \%$ at 49 days; in treatment 4 from 0.07 to $0.35 \%$ ). The number of protein fractions (with molecular weights from 100 to $<20 \mathrm{KDa}$ ) in meat increased with slaughter age with all studied diets. Protein of breast muscles contained more isoleucine, leucine, valine, and phenylalanine at 38 and 49 days of age in compare to thigh meat with all studied diets. The digestibility of essential amino acids in breast muscles in treatment 4 grew from $81.78 \%$ with slaughter at 38 days to $90.29 \%$ at 49 days. Evaluation of biological value of meat revealed better balanced ratios of the essential amino acids in breast muscles in control treatment at 38 days of age (the difference in the amino acid score $70.53 \%$ ) and in treatment 4 at 49 days of age (the difference in the amino acid score $66.48 \%$ ). In thigh meat this difference was higher in treatment 3 at 38 days of age $(59.69 \%)$ and in treatment 4 at 49 days of age $(61.43 \%)$. There were no significant differences between the treatments in concentrations of fatty acids in meat. The conclusion was made that the use of new protein additives based on the enzymatic hydrolysates of feathers and collagen in diets for broilers does not deteriorate the parameters of meat quality.

Keywords: broiler chicks, feed additives, feathers, collagen, enzymatic hydrolysates, live bodyweight, meat quality, amino acid score, fatty acids, essential nutrients, technological traits.

\section{R E F E R E N C E S}

1. Shim Y., Kim J., Hosseindoust A., Choi Y., Kim M., Oh S., Ham H., Kumar A., Kim K., Jang A., Chae B. Investigating meat quality of broiler chickens fed on heat processed diets containing corn distillers dried grains with solubles. Korean Journal for Food Science of Animal Resources, 2018, 38(3): 629-635 (doi: 10.5851/kosfa.2018.38.3.629).

2. Erisanov O., Ulit'ko V. Ptitsevodstvo, 2009, 3: 34-36 (in Russ.).

3. van Harn J., Dijkslag M.A., van Krimpen M.M. Effect of low protein diets supplemented with free amino acids on growth performance, slaughter yield, litter quality, and footpad lesions of male broilers. Poultry Science, 2019, 98(10): 4868-4877 (doi: 10.3382/ps/pez229).

4. Lenkova T.N., Egorov I.A., Egorova T.A., Manukyan V.A., Vertiprakhov V.G., Grozina A.A., Nikonov I.N., Filippova V.A., Iyldyrym E.A., Ilina L.A., Dubrovin A.V., Laptev G.Yu. Intestinal microbiota and broiler performance upon administration of phytase to increase phosphorus digestibility and nutrient utilization from feed. Agricultural Biology [Sel'skokhozyaistvennaya biologiya], 2020, 55(2): 406-416 (doi: 10.15389/agrobiology.2020.2.406eng).

5. Sleman S.M., Swick Robert A., Iji Paul A. Specialized protein products in broiler chicken nutrition: A review. Anim Nutr.,2015, 1(2): 47-53 (doi: 10.1016/j.aninu.2015.05.005).

6. Kornilov V. Kachestvo myasa v zavisimosti ot tekhnologii soderzhaniya broilerov. Ptitsevodstvo, 2009, 2: 32-34 (in Russ.).

7. Disetlhe A.R.P., Marume U., Mlambo V., Hugo A. Effects of dietary humic acid and enzymes on meat quality and fatty acid profiles of broiler chickens fed canola-based diets. Asian-Australas. J. Anim. Sci., 2019, 32(5): 711-720 (doi: 10.5713/ajas.18.0408).

8. Mir N.A., Rafiq A., Kumar F., Singh V., Shukla V. Determinants of broiler chicken meat quality and factors affecting them: a review. J. Food Sci. Technol., 2017, 54(10): 2997-3009 (doi: 10.1007/s13197-017-2789-z).

9. Altmann B.A., Neumann C., Velten S., Liebert F., Mörlein D. Meat quality derived from high inclusion of a micro-alga or insect meal as an alternative protein source in poultry diets: a pilot study. Foods, 2018, 7(3): 34 (doi: 10.3390/foods7030034).

10. Kuźniacka J., Banaszak M., Biesek J., Maiorano G., Adamski M. Effect of faba bean-based diets on the meat quality and fatty acids composition in breast muscles of broiler chickens. Sci. Rep., 2020, 10: 5292 (doi: 10.1038/s41598-020-62282-7). 
11. Perween S., Chandramoni K., Kumar S., Kumar Singh P., Kumar M., Dey A. Effect of feeding different dietary levels of energy and protein on growth performance and immune status of Vanaraja chicken in the tropic. Vet. World, 2016, 9(8): 893-899 (doi: 10.14202/vetworld.2016.893899).

12. Widyaratne G.P., Drew M.D. Effects of protein level and digestibility on the growth and carcass characteristics of broiler chickens. Poultry Science, 2011, 90(3): 595-603 (doi: 10.3382/ps.201001098).

13. Sigolo S., Zohrabi Z., Gallo A., Seidavi A., Prandini A. Effect of a low crude protein diet supplemented with different levels of threonine on growth performance, carcass traits, blood parameters and immune responses of growing broilers. Poultry Science, 2017, 96(8): 2751-2760 (doi: $10.3382 / \mathrm{ps} / \mathrm{pex} 086)$.

14. Ross M.L., Bryan D.D.S.L., Abbott D.A., Classen H.L. Effect of protein sources on performance characteristics of turkeys in the first three weeks of life. Anim. Nutr., 2019, 5(4): 396-406 (doi: 10.1016/j.aninu.2019.09.002).

15. León-López A., Morales-Peñaloza A., Martínez-Juárez V.M., Vargas-Torres A., Zeugolis D.I., Aguirre-Álvarez G. Hydrolyzed collagen - sources and applications. Molecules, 2019, 24(22): 4031 (doi: 10.3390/molecules24224031).

16. Han Y., Parsons C.M. Determination of available amino acids and energy in alfalfa meal, feather meal, and poultry by-product meal by various methods. Poultry Science, 1990, 69(9): 1544-1552 (doi: 10.3382/ps.0691544).

17. Hong H.A., Huang J.M., Khaneja R., Hiep L.V., Urdaci M.C., Cutting S.M. The safety of Bacillus subtilis and Bacillus indicus as food probiotics. J. Appl. Microbiol., 2008, 105: 510-520 (doi: 10.1111/j.1365-2672.2008.03773.x).

18. Hanning I., Clement A., Owens C., Park S.H., Pendleton S., Scott E.E., Almeida G., Gonzalez Gil F., Ricke S.C. Assessment of production performance in 2 breeds of broilers fed prebiotics as feed additives. Poultry Science, 2012, 91(12): 3295-3299 (doi: 10.3382/ps.2012-02557).

19. Tavaniello S., Maiorano G., Stadnicka K., Mucci R., Bogucka J., Bednarczyk M. Prebiotics offered to broiler chicken exert positive effect on meat quality traits irrespective of delivery route. Poultry Science, 2018, 97(8): 2979-2987 (doi: 10.3382/ps/pey149).

20. Cramer T.A., Kim H.W., Chao Y., Wang W., Cheng H.W., Kim Y.H.B. Effects of probiotic (Bacillus subtilis) supplementation on meat quality characteristics of breast muscle from broilers exposed to chronic heat stress. Poultry Science, 2018, 97(9): 3358-3368 (doi: 10.3382/ps/pey 176).

21. Alfaig E., Angelovičova M., Kral M., Bučko O. Effect of probiotics and thyme essential oil on the essential amino acid content of the broiler chicken meat. Acta Sci. Pol. Technol. Aliment., 2014, 13(4): 425-432 (doi: 10.17306/J.AFS.2014.4.9).

22. Okolelova T.M., Prosviryakova O.A, Grigor'eva E.N., Shevyakov A.N. Ptitsa i ptitseprodukty, 2008, 2: 41-43 (in Russ.).

23. Lisunova, L.I., Tokarev V.S., Larin V.V. Ptitsevodstvo, 2007, 9: 47-48 (in Russ.).

24. Poletaev A.Yu., Kurbanova M.G. Tekhnika i tekhnologiya pishchevykh proizvodstv, 2010, 18(3): 29-34 (in Russ.).

25. Ganenko S.V., Stolbovaya E.I., Starikova N.A., Prokopov Ts.V. APK Rossii, 2015, 72(2): 9196 (in Russ.).

26. Eaksuree W., Prachayakitti A., Upathanpreecha T., Taharnklaew R., Nitisinprasert S., Keawsompong S. In vitro and in vivo evaluation of protein quality of enzymatic treated feather meals. SpringerPlus, 2016, 5(1): 971 (doi: 10.1186/s40064-016-2626-2).

27. Cansu Ü, Boran G. Optimization of a multi-step procedure for isolation of chicken bone collagen. Korean J. Food Sci. Anim. Resour., 2015, 35(4): 431-440 (doi: 10.5851/kosfa.2015.35.4.431).

28. Eremeev N.L., Nikolaev I.V., Keruchen'ko I.D., Stepanova E.V., Satrutdinov A.D., Zinov'ev S.V., Ismailova D.Yu., Khotchenkov V.P., Tsurikova N.V., Sinitsyn A.P., Volik V.G., Koroleva O.V. Prikladnaya biokhimiya $i$ mikrobiologiya, 2009, 45(6): 717-724 (doi: 10.1134/S0555109909060130) (in Russ.).

29. Mamelona J., Saint-Louis R., Pelletier E., Mamelona J. Nutritional composition and antioxidant properties of protein hydrolysates prepared from echinoderm byproducts. Int. J. Food Sci. Technol, 2010, 45: 147-154 (doi: 10.1111/j.1365-2621.2009.02114.x).

30. Khiari Z., Ndagijimana M., Betti M. Low molecular weight bioactive peptides derived from the enzymatic hydrolysis of collagen after isoelectric solubilization precipitation process of turkey byproducts. Poultry Science, 2014, 93: 2347-2362 (doi: 10.3382/ps.2014-03953).

31. Fisinin V.I., Lukashenko V.S., Saleeva I.P., Ovseichik E.A., Zhuravchuk E.V., Volik V.G., Ismailova D.Yu. Ptitsevodstvo, 2018, 11-12: 20-22 (in Russ.).

32. Volik V.G., Ismailova D.Yu., Lukashenko V.S., Saleeva I.P., Fedorova T.V., Ovseichik E.A., Zhuravchuk E.V., Zinov'ev S.V. Uchenye zapiski Kazanskogo universiteta, seriya estestvennye nauki, 2019, 161(3): 422-439 (in Russ.).

33. Fisinin V.I., Ismailova D.Yu., Volik V.G., Lukashenko V.S., Saleeva I.P. Deep processing of collagen-rich poultry products for different use (review). Agricultural Biology [Sel'skokhozyaistvennaya biologiya], 2017, 52(6): 1105-1115 (doi: 10.15389/agrobiology.2017.6.1105eng). 
34. Nikolaev I.V., Sforza S., Lambertini F., Ismailova D.Yu., Khotchenkov V.P., Volik V.G., Dossena A., Popov V.O., Koroleva O.V. Biocatalytic conversion of poultry processing leftovers: optimization of hydrolytic conditions and peptide hydrolysate characterization. Food Chemistry, 2016, 197(Part A): 611-621 (doi: 10.1016/j.foodchem.2015.10.114).

35. Hou Y., Wu Z., Dai Z., Wang G., Wu G. Protein hydrolysates in animal nutrition: industrial production, bioactive peptides, and functional significance. J. Anim. Sci. Biotechnol., 2017, 8: 24 (doi: 10.1186/s40104-017-0153-9).

36. Ivankin A.N., Oliferenko G.L., Kulikovskii A.V., Chernukha I.M., Semenova A.A., Spiridonov K.I., Nasonova V.V. Zhurnal analiticheskoi khimii, 2016, 71(11): 1188-1195 (in Russ.).

37. Zhuravskaya N.K., Alekhina L.T., Otryashenkova L.M. Issledovanie i kontrol' kachestva myasa $i$ myasoproduktov. Moscow, 1985 [Research and quality control of meat and meat products] (in Russ.).

38. Eady M., Samuel D., Bowker B. Effect of $\mathrm{pH}$ and postmortem aging on protein extraction from broiler breast muscle. Poultry Science, 2014, 93(7): 1825-1833 (doi: 10.3382/ps.2013-03619).

39. El-Senousey H.K., Fouad A.M., Yao J.H., Zhang Z.G., Shen Q.W. Dietary alpha-lipoic acid improves body composition, meat quality and reduces the collagen content in the muscles of broiler chickens. Asian-Australas. J. Anim. Sci., 2013, 26(3): 394-400 (doi: 10.5713/ajas.2012.12430).

40. Li J., Yang C., Peng H., Yin H., Wang Y., Hu Y., Yu C., Jiang X., Du H., Li Q., Liu Y. Effects of slaughter age on muscle characteristics and meat quality traits of Da-Heng meat type birds. Animals, 2020, 10(1): 69 (doi: 10.3390/ani10010069).

41. Bowker B., Zhuang H. Relationship between water-holding capacity and protein denaturation in broiler breast meat. Poultry Science, 2015, 94(7): 1657-1664 (doi: 10.3382/ps/pev120).

42. Chen Y., Qiao Y., Xiao Y., Chen H., Zhao L., Huang M., Zhou G. Differences in physicochemical and nutritional properties of breast and thigh meat from crossbred chickens, commercial broilers, and spent hens. Asian-Australas. J. Anim. Sci., 2016, 29(6): 855-864 (doi: 10.5713/ajas.15.0840).

43. Haščík P., Pavelkov, A., Tkáčová J., Čuboň J., Kačániová M., Habánová M., Mlyneková E. The amino acid profile of broiler chicken meat after dietary administration of bee products and probiotics. Biologia, 2020, 75: 1899-1908 (doi: 10.2478/s11756-020-00451-9).

44. Knyazeva A.S., Vostrikova N.L., Ivankin A.N., Kulikovskii A.V. Vse o myase, 2017, 2: 36-39 (in Russ.).

45. Rymer C., Gibbs R., Givens D. The relationship between the unsaturated fatty acid profile of poultry meat and volatile aldehydes formed in meat. Proceedings of the British Society of Animal Science, 2007, 2007: 18 (doi: 10.1017/S1752756200019219).

46. del Puerto M., Cabrera M.C., Saadoun A. Note on fatty acids profile of meat from broiler chickens supplemented with inorganic or organic selenium. International Journal of Food Science, 2017, 2017: 7613069 (doi: 10.1155/2017/7613069). 